\title{
EFFECTS OF SHEEP ENDOMETRIAL GRAFTS AND EXTRACTS ON THE LENGTH OF PSEUDOPREGNANCY IN THE HYSTERECTOMIZED HAMSTER
}

\author{
B. V. GALDWELL, ${ }^{*}$ R. M. MOOR AND R. A. S. LAWSON \\ A.R.C. Unit of Reproductive Physiology and Biochemistry, University of Cambridge $\dagger$
}

(Received 19th Fuly 1968)

The normal length of pseudopregnancy in hamsters ( 9.2 days) is doubled (18 days) following hysterectomy. Transplanting either one hamster uterine horn, or pieces of endometrium to the cheek pouch of hysterectomized animals significantly reduces the length of induced pseudopregnancy from 18 to 13.5 days (Caldwell, Mazer \& Wright, 1967). These authors also reported that transplanting rat uteri to the cheek pouch also reduced pseudopregnancy in hysterectomized hamsters ( $14 \cdot 8$ days), whereas the effects of transplanting rabbit uteri ( 15.5 days) were not as conclusive. Human endometrium had no apparent shortening influence on the pseudopregnancy cycle length (17.5 days).

These results suggested that the regulatory effect of the uterus on the life span of corpora lutea may not be species specific and the present study was initiated to investigate the influence of sheep endometrium and endometrial preparations on the length of copulation-induced pseudopregnancy in hysterectomized hamsters. Previous studies on sheep (Wiltbank \& Casida, 1956; Moor \& Rowson, 1964) showed that hysterectomy prolongs the life span of corpora lutea to 145 days and recent experiments have established that autotransplantation of endometrium significantly reduces this extended period to 35 to 40 days (Rowson, Moor, Hay \& Caldwell, unpublished).

Mature female hamsters weighing between 85 and $125 \mathrm{~g}$ were totally hysterectomized under Nembutal $(8 \mathrm{mg} / 100 \mathrm{~g}$ body $\mathrm{wt}$ ) and allowed 6 to 10 days as a post-operative recovery period. Fertile males were then placed with the individually caged animals and the females observed for signs of oestrus (lordosis). At least one normal 4-day oestrous cycle was recorded before mating was permitted to occur and the resulting length of pseudopregnancy was taken to be the same as the period before the appearance of the next oestrus. Sheep endometrium was stripped from the myometrium and cut into small pieces before being inserted between the inner membranes of the hamster cheek pouch as previously described for other tissue (Caldwell, Pawling \& Wright, 1966).

* Present address: Worcester Foundation for Experimental Biology, Shrewsbury, Massachusetts, U.S.A.

† Postal address: Animal Research Station, 307 Huntingdon Road, Cambridge, England. 
When endometrium was obtained from sheep on the 3rd or 6th day following oestrus and transplanted to hamsters on Day 9 of pseudopregnancy, no significant shortening of this cycle length was observed in seven of the eight animals tested (Table 1, Group 1). However, when the endometrium was taken from sheep on Day 14 or 15 of the oestrous cycle and transplanted in the same manner, this resulted in significant shortening of pseudopregnancy in eight out of thirteen hamsters (Table 1, Group 2).

Sheep endometrium was homogenized in distilled water and freeze-dried under a partial vacuum for about $24 \mathrm{hr}$. This lyophilized material (approx. $1 \mathrm{~g}$ /uterus) was powdered in a Waring blender and stored at $-20^{\circ} \mathrm{C}$ until ready for use. Aqueous extracts were prepared by adding the endometrial

TABLE 1

DURATION OF PSEUDOPREGNANGY IN HYSTEREGTOMIZED HAMSTERS AS INFLUENGED BY SHEEP ENDOMETRIAL TRANSPLANTS AND EXTRAGTS

\begin{tabular}{|c|c|c|c|c|c|c|c|c|c|}
\hline \multirow[b]{2}{*}{ Group } & \multirow[b]{2}{*}{ Treatment } & \multirow{2}{*}{$\begin{array}{l}\text { No. of } \\
\text { animals }\end{array}$} & \multirow{2}{*}{$\begin{array}{l}\text { Physiological age } \\
\text { of endometrium } \\
\text { during sheep } \\
\text { oestrous cycle }\end{array}$} & \multicolumn{6}{|c|}{ Days duration of pseudopregnancy* } \\
\hline & & & & $\begin{array}{r}f \\
<14\end{array}$ & $\begin{array}{l}\text { treat } \\
>14\end{array}$ & Meant & $\begin{array}{r}P \\
<14\end{array}$ & $\begin{array}{c}\text { t-treat } \\
>14\end{array}$ & $\begin{array}{l}\text { ent } \\
\text { Mean }\end{array}$ \\
\hline 1 & $\begin{array}{l}\text { Transplantation } \\
\text { to cheek pouch }\end{array}$ & 8 & Day 3 and 6 & 1 & 7 & $17 \cdot 5$ & 1 & 7 & $16 \cdot 4$ \\
\hline 2 & $\begin{array}{l}\text { Transplantation } \\
\text { to cheek pouch }\end{array}$ & 13 & Day 14 and 15 & 1 & 12 & $18 \cdot 0$ & 8 & 5 & $12 \cdot 4$ \\
\hline 3 & $\begin{array}{l}\text { Intraperitoneal } \\
\text { injection of } \\
\text { aqueous extracts }\end{array}$ & 9 & Day 6 and 9 & 0 & 9 & $17 \cdot 0$ & 1 & 8 & $16 \cdot 0$ \\
\hline 4 & $\begin{array}{l}\text { Intraperitoneal } \\
\text { injection of } \\
\text { aqueous extracts }\end{array}$ & 16 & Day 14 and 15 & 1 & 15 & $19 \cdot 5$ & 9 & 7 & $14 \cdot 5$ \\
\hline
\end{tabular}

* Normal pseudopregnancy about 9 days. Pseudopregnancy following hysterectomy about 18 days.

powders $(30 \mathrm{mg} / \mathrm{ml})$ to saline solution. A homogeneous mixture was achieved by grinding the suspension with a glass rod, and the preparation remained at room temperature for $30 \mathrm{~min}$. Centrifuging the mixture at $3500 \mathrm{rev} / \mathrm{min}$ produced a firm pellet and a supernatant. The latter was removed and made sterile by passing through a Millipore filter, and injected $(1 \mathrm{ml})$ intraperitoneally to hysterectomized hamsters on Days 9 and 10 of pseudopregnancy (approx. $1 \mathrm{mg} / \mathrm{ml}$ ). The length of pseudopregnancy was not significantly altered by extracts prepared from sheep on Days 6 and 9 of the oestrous cycle (Group 3), whereas nine out of sixteen hamsters had cycle lengths of less than 14 days when extracts from endometrium on Days 14 and 15 were injected (Group 4).

These results agree well with the recent work of Mazer \& Wright (1968) who showed that hamster extracts prepared from Day-7 pseudopregnant uteri were effective in shortening pseudopregnancy when injected into hysterectomized animals. They also suggested that the 'luteolytic' influence was present in the submitochondrial fraction of cellular homogenates and that this 'uterineluteolytic-factor' was not effective in destroying pregnancies when injected on Days 5 to 8 . Current work in this laboratory supports this finding since in ten 
hamsters tested with the sheep endometrial extracts all the pregnancies resulted in normal litters.

The results of all the investigations suggest that the hysterectomized hamster may be a suitable bio-assay animal for detecting substances which may influence the functional life span of corpora lutea. However, until the specificity of both the assay system and the endometrial extracts has been studied further, these findings should be viewed with some caution. Nevertheless, a growing weight of evidence is accumulating to support the view that the endometrium of several species may produce an effect which is involved in the regulation of corpora lutea life span.

\section{REFERENCES}

CAldwell, B. V., MAzer, R. S. \& WRight, P. A. (1967) Luteolysis as affected by uterine transplantation in the Syrian hamster. Endocrinology, 80, 477.

Caldwell, B. V., Pawling, R. S. \& Wright, P. A (1966) Re-establishment of ovarian periodicity after transplantation to the Syrian hamster cheek pouch. Proc. Soc. exp. Biol. Med. 123, 551.

MAZER, R. S. \& WRIGHT, P. A. (1968) A hamster uterine luteolytic extract. Endocrinology. (In press).

Moor, R. M. \& Rowson, L. E. A. (1964) Influence of the embryo and uterus on luteal function in sheep. Nature, Lond. 201, 522.

Wiltbank, J. N. \& Casida, L. E. (1956) Alteration of ovarian activity by hysterectomy. F. Anim. Sci. 15,134 . 